sciendo Порівняльна професійна педагогіка 9(2)/2019 Comparative Professional Pedagogy 9(2)/2019

DOI: $10.2478 /$ rpp-2019-0019

Postgraduate Student, ALINA MEDYNSKA

Khmelnytskyi National University

Address: 11 Instytutska St., Khmelnytskyi, 29016, Ukraine

E-mail: medunya1@gmail.com

\title{
THE CHARACTERISTICS OF SUBJECT-SUBJECT INTERACTION DURING PROFESSIONAL TRAINING OF FUTURE FOREIGN LANGUAGE TEACHERS AT FRENCH UNIVERSITIES
}

\begin{abstract}
The article studies the conditions of the educational environment in higher education institutions in France, especially at pedagogical universities, in order to explore the psychological conditions for developing competencies in future foreign language teachers. The article thoroughly analyzes the studies of French scholars on the interaction between the participants in the educational process. There are two main trends in sociological studies on educational relationship. The first theory proves the impossibility of abstracting the interaction between teachers and students from the organization of teacher education and its role in society and highlights the interaction in the division of labour. The second theory lies in studying the interaction between the subjects as a social reality, which occurs as a result of implementing certain interactions. The article considers the effects of mass formation in the context of such areas as degradation and remotization of interactions during professional training. It also describes the results of observations on the subjects of educational activity conducted by certain French scholars between the early 20th century and the early 21st century. The studies between 1975 and 2000 reveal the effects of massification in the social and public environment. The image of French universities of that period is characterized by overload and degradation in the relational context. The authors point to the weakness of integration between students, misunderstandings with teachers and, finally, the distance of communication. The early 21st century has not yet much contributed to the professional training of future foreign language teachers in the context of educational relationship between the participants in the educational process. The article analyzes possible explanations of relational difficulties. These, first of all, include unjustified expectations of the subjects of both parties. In addition, one of the most important influential factors is pedagogical mastery of communication quality. However, one of the most important reasons is the quality of human relationships. The current period in professional teacher training is characterized by a gap in the interaction between students and teachers as a result of introducing technologies, acquiring virtual knowledge and culture of instant information.

Keywords: subject-subject interaction, teacher-student interaction, French universities, pedagogical mastery, professional competency, teacher training, sociological survey, relational difficulties, university integration.
\end{abstract}

\footnotetext{
АНОТАЦІЯ

Статтю присвячено дослідженню стану освітнього середовища у вищих навчальних закладах Франиії, зокрема в педагогічних університетах, 3 метою вивчення психологічних умов для розвитку компетентностей майбутніх вчителів
} 
sciendo Порівняльна професійна педагогіка 9(2)/2019 Comparative Professional Pedagogy 9(2)/2019

іноземних мов. Проведено детальний аналіз пращь франиузьких науковців щзодо взаємодії між учасниками навчально-виховного прочесу. Виділено дві основні тенденції в сочіологічних дослідженнях суб'єкт-суб'єктних відносин. Перша теорія доводить неможливість абстрагування стосунків між викладачами та студентами від організації системи педагогічної освіти та ї̈ ролі у соціумі, висвітлює відносини у розподілі праці. Основа другої теорії полягає в дослідженні взаємозв'язку між суб' єктами як сочіальної реальності, щзо виникає внаслідок провадження комплексу взаємодій. Розглянуто ефект масоутворення за напрямками деградації та дистаниіювання стосунків в процесі професійної підготовки. Описано результати спостережень за суб'єктами освітньої діяльності низки франиузьких вчених в період кіния минулого та першої декади XXI століття. Дослідження з 1975 по 2000 рр. розкривають наслідки масифікацї у сочіальному і громадському середовищі. Образ франиузького університету иього періоду характеризується перенавантаженням $i$ деградацісю в реляційному контексті. Автори вказують на слабкість інтеграції студентів, непорозуміння з викладачами, віддаленість у спілкуванні. Початок XXI століття в підготовці майбутніх вчителів іноземних мов також не відзначився великим задоволенням в суб' єкт-суб' єктних відносинах між учасниками навчального прочесу. В статті проаналізовано можслві пояснення реляційних труднощів. Це, в периу чергу, невиправдані очікування суб'єктів обох сторін. Крім того, одним із найважливіших факторів впливу є педагогічна майстерність якості спілкування. $A$ також, однією з найвагоміших причин, є якість людських стосунків. Сучасний період в професійній підготовиі вчителів характеризується розривом у відносинах студентів з викладачами внаслідок впровадження технологій, набуття віртуальних знань та культури миттєвої інформації.

Ключові слова: суб'єкт-суб'єктні відносини, взаємодія викладача і студента, університет Франиії, педагогічна майстерність, професійна компетентність, підготовка вчителів, сочіологічне опитування, релячійні труднощі, університетська інтеграчія.

\section{INTRODUCTION}

Under today's conditions, the quality of training any specialist and teacher, in particular, is determined not only by the level of his/her knowledge but also by professional skills that allow him/her to creatively solve potential problems, actively interact with people based on establishing educational relationship. In the context of the professional training for future foreign language teachers, higher education should incorporate a wide range of tools for developing relevant skills. When studying the development of competencies in future teachers, it is necessary to take into account the psychological conditions of the internal environment in higher education institutions.

The educational process involves the interaction between teachers and students, which influences the implementation of educational activities and the quality of professional training. The relationships in the student-teacher system serve as the psychological domain, where personal self-affirmation of a future specialist occurs for the first time, his/her self-awareness develops and a model of professional activity is assimilated. The interaction between teachers and students in a pedagogical institution implies special relationships between the teacher and the student (vertical relationships) and relationships with future colleagues (horizontal relationships) (Mykytiuk, 2003).

Given the interest of Ukrainian pedagogy in the Western model of implementing educational and research activities in higher education, it is vital to study the French experience as the leading one in Europe. 
Educational relationship within the university is a relatively unexplored field of research in France. However, certain works that are not sufficiently covered by Ukrainian scholars can be used in comparative pedagogy of Ukraine. Basically, these are sociological surveys relating to the university issue as a whole, pedagogical activities and student experiences, which are discussed by French scholars in terms of content and methods (P. Bourdieu, R. Boyer, C. Coridian, A. Coulon, F. Dubet, S. Paivandi, J.-C. Passeron). However, a few studies have been conducted on the educational environment in higher education institutions in the course of students' accepting their own autonomy and eliminating school dependence, which arose in the previous period. Such a pressing state can be justified by the difficulties in conducting an academic analysis of academic practice. Still, under such conditions, educational relationship loses its importance and no longer is a decisive problem in the educational process at universities (Coulon, \& Paivandi, 2008).

The author believes that this determines the relevance of the current research, especially in the context of introducing information and computer and digital technologies in educational institutions in the leading countries of the world, in particular, France and Ukraine, within which a new form of influence on the interaction between teachers and students in higher education institutions is possible since it is one of the components of effective professional training for future foreign language teachers.

\section{THE AIM OF THE STUDY}

The article aims to provide an analytical review of the French experience in educational relationship during the professional training of future foreign language teachers, identify possible influential factors and analyze the difficulties in the interaction between teachers and students at French universities.

\section{THEORETICAL FRAMEWORK AND RESEARCH METHODS}

Ukrainian pedagogy considers educational relationship mainly in the context of studying various aspects of pedagogical communication (N. Holiardyk, V. Kan-Kalyk, L. Savenkova, N. Starovoitenko et al.). Some studies were devoted to the relationships between teachers and students: general issues of psychology of pedagogical interaction in higher education (I. Bekh, O. Korolchuk, D. Kriukova, H. Mykytiuk, I. Ziaziun et al.); a dialogical interaction between the teacher and the student as a prerequisite of personal and professional growth of future teachers (L. Dolynska, V. Semychenko); psychological aspects of an interpersonal interaction between teachers and students (I. Bulakh, L. Dolynska); the influence of relationships between teachers and students on the process of forming the "self-concept" in future teachers (V. Yurchenko), etc.

However, the above-mentioned types of research were conducted only in the Ukrainian system of higher education. The Western experience of relationships between the participants in the educational process has not been sufficiently studied by Ukrainian science.

To achieve the set aim, such methods as analysis, synthesis, generalization and systematization were used.

\section{RESULTS}

Two trends in the perception of relationships. The two main trends can be distinguished in sociological studies on the relationships between students and teachers at French universities. The first attempts were made to demonstrate the impossibility of abstracting educational relationship from the organization of teacher education, its social functions and connections with the global society. According to this theory, the system of education highlights the relationships in the division of labour. The teacher is seen as a representative of the "legitimate" culture and an agent of cultural selection. Pedagogical 
sciendo Порівняльна професійна педагогіка 9(2)/2019 Comparative Professional Pedagogy 9(2)/2019

modality is also perceived as a practice of symbolic control, based on the gradual hierarchy of positions and processes of cultural reproduction. P. Bourdieu \& J.-C. Passeron (1964) believe that teachers have already tried to leave the platform without abandoning their "ultimate protection, professorial use of the language of instruction" or "language abuse". These sociological data exclude any "compensatory" movement. Therefore, educational relationship is considered as non-dialectical relationships based on a graded hierarchy of positions.

The second trend, rejecting mechanical and linear determinism, seeks to investigate the interconnection between educational partners as a social reality arising at the heart of a complex of interactions, transformations and operations between the subjects involved in activities. The university is not only a basis for reproducing social relations, which exist outside its borders. It is also a place where social phenomena are developed and educational partners are subjectivized. There, there are also differences and tensions inherent in the institutional educational link, namely cultural conflict, asymmetry, authority, attitude towards differentiated knowledge, exclusion, generational disagreement, relationships with the authorities. The connection between the participants in the educational process is not limited to the existential dimension (an event, here and now) since it simultaneously involves a temporary measure (recorded in duration, at the level of individual persons) and the historicity of the groups and the immediate environment (Pinel, 2003).

The effects of mass formation: degradation and remotization of relationships. According to these two main directions, a significant number of sociological studies on universities took place between 1975 to 2000 . The consequences of massification in the social and public environment are emphasized; the provocation of "social and cultural gap between universities and students" is described (Fave-Bonnet, 2003, p. 34). The image of French universities of that period is characterized by the overload and degradation in the relational context. The state of relationships between participants in the educational process, described by the scholars, very often corresponds to the first "non-selective" university cycles, in which such phenomena as failure, reorientation and refusal are prevailing. The studies on student behaviour focus on their critical remarks oriented towards some aspects of the human environment: the disadvantages of primary acceptance, the complicated relationships with teachers, weak communication skills (Coulon, \& Paivandi, 2008).

The pedagogical forms of French universities offer a rather free structure that complicates the transition from secondary to higher education, as well as the study of the student's profession. Institutional expectations and goals of university education actually assign different roles for students compared to secondary education. J. Guyot's work (1979) was one of the first studies in this field devoted to the interaction between the participants in the educational process. The author attempts to show that "a physical distance reflects an already existing psychological distance in communication" (Guyot, 1979, p. 164). G. Felouzis (2001) describes "the student world" as an atomized universe, with a very weak integration, in which "the relationships with teachers are combined with misunderstanding" (p. 213). R. Boyer \& C. Coridian (2002) highlight the results obtained from a survey of future teachers, who lack support from their teachers. Junior students support occasional and distant relationships with their teachers, while senior students are more likely to need regular communication. P. Merle's survey (1997) attempts to cover various factors associated with the development or lack of contact between the two partners. According to the author, "communicating with the teacher is rather difficult for students: it implies a gap in status and power" (p. 381). The results of another survey, conducted by C. Hadji, T. Bargel, \& J. Masjuan (2004) in three countries (France, Germany, Spain), show that only 
one-third of students studying in higher education institutions, in particular, future foreign language teachers, maintain frequent relationships with teachers.

In the late 20th century, a three-year observation on student life was conducted by the Sociological Laboratory (OVE), which involved a large research sample (an average of 25,000 students). The review of the conducted work reproduced the process of studying the interaction between the participants in the educational process. The comparison of the results from the five surveys between 1997 and 2000 shows that as B. Lahire (2000) noted, "student ratings were not characterized by special "enthusiasm" (p. 308).

The first decade of the 21 st century has not been marked by special progress. The 2010 survey also confirms that educational relationship rarely involves mass satisfaction and demonstrates a clear gap between the selective sector (more "satisfied") and the university (Pinel, 2003).

Possible explanations of relational difficulties. Some problems are often mentioned in student discourse upon the relationships with teachers. The first point relates to an understanding of teachers' expectations. It must be noted that especially first and secondyear students find it difficult to comprehend the content of educational discourse and realize actual expectations from them (homework, part-time study). For one, the general educational atmosphere is more often viewed as "relaxed and enjoyable when students perceive the teacher at the proper level" (Merle, 1997, p. 333). The second point concerns both pedagogical mastery and quality of communication demonstrated by the teacher at the lesson. The third critical point involves human relationships at the university. Students are often disappointed with the weakness of the very human relationships. Some surveys show that educational institutions with small capacity and a low number of education providers create "more favourable" conditions for more tolerant relationships (Felouzis, 2001).

On the other hand, the studies published by French scholars also often criticize students. The worldviews of participants in the educational process seem to be alien to each other (Coulon, \& Paivandi, 2008). According to the authors, teachers have different views on their students, although with the systematic gap between expectations and the culture of students and their own. The prevailing discourses coincide with the idea that disadvantages always occur because of students. As evidenced by D. Martuccelli (1995), "teachers are unanimous in condemning "the invasion of the logic of knowledge through the logic of expertise". Thus, the teacher perceives the student as a problematic category because he/she is constantly in opposition. The author believes that the teacher lives in a radically different world from his/her student (Martuccelli, 1995, p. 123). Teachers assume that the massification impedes their relationship with students, making any personalized report impossible.

Showing some interest in educational relationship in higher education institutions, F. Dubet (1994) presented a "human" dimension in the student experience. He believes that there are the following three systems in it: the institution);

- a community structured according to the logic of integration (an integration with

- one or several competitive markets according to the logic of strategy (a projectbased dimension);

- a cultural system that corresponds to the logic of subjectivation (estimating vocation).

According to F. Dubet (1994), the student is obliged to formulate the logic of different actions, and the very dynamics of this activity reflects its subjectivity and reflexivity. "These dimensions are determined by the subjects based on their compliance with the standards of organization and the environment of the university, intellectual 
sciendo Порівняльна професійна педагогіка 9(2)/2019 Comparative Professional Pedagogy 9(2)/2019

interest, vocation" (Dubet, 1994, p. 512). Therefore, F. Dubet (1994) offers a theoretical model comprising eight categories of students after combining these three dimensions, which constitute student experience.

In the context of the interconnection with the environment designed by F. Dubet (1994), people are at the heart of a living part of the experience. However, the author is quite critical about the relational aspect of student life in higher education institutions, especially in relation to teachers.

According to the scholar, some distance prevails in the image of the teacher, namely social, cultural and physical. This implies the need for the student to motivate himself/herself "to create his/her own experience".

F. Dubet (1994) shows that a mass university is a multiple reality, which requires that education faculties should offer a more integrated structure, "every student builds his/her own form and level of participation and integration in the organization where the research was conducted. The student is more exposed to the stronger influence of the surrounding environment than an educational one, where integration is not so widespread" (p. 515).

There is a certain gap between students with classical cultural forms in favour of image, technology, virtual, "useful" knowledge, the culture of instant information in the relationships between future foreign language teachers and their teachers, during the professional training at French universities, as well as at other faculties.

Thus, the influence of modern mutations on the relational context has become the object of criticism since educational institutions are characterized by technological culture, prevailing individualism and "the emergence of youth as a cultural value". The new generation seems to be less hard-working, respect teachers less and begin the era of exaggeration in the freedom of speech, taking a more "bold" position in behaviour in relation to the teaching authority (Pinel, 2003).

\section{CONCLUSIONS}

In the process of studying the conditions for developing competencies in teachers, there appears to be a need to study the psychological conditions of the internal educational environment in educational institutions. An analytical review of French scholars' works indicates only a few research on educational relationship during the professional training of future foreign language teachers. In addition, the results of the conducted studies prove that teachers are not so much interested in promoting education and human investment. The conducted analysis of students' involvement into university life and causes of possible difficulties in the interaction between teachers and students demonstrates the widespread use of information and communication technologies in the modern world as the main source of breaking off the relationships between participants in the educational process.

The prospects of further studies involve considering the general framework for introducing digital technologies and tools for instant virtual communication at French universities, as well as identifying and analyzing the factors in the possible influence of information and communication technologies on educational relationships in the system of higher education.

\section{REFERENCES}

1. Bourdieu, P., \& Passeron, J.-C. (1964). Les héritiers. Les étudiants et la culture. Paris: Les Éditions de Minuit.

2. Boyer, R., \& Coridian, C. (2002). Transmission des savoirs disciplinaires dans l'enseignement universitaire. Sociétés contemporaines, 48, 41-61. 
sciendo Порівняльна професійна педагогіка 9(2)/2019 Comparative Professional Pedagogy 9(2)/2019

3. Coulon, A., \& Paivandi, S. (2008). Les relations entre les étudiants, les enseignants et le personnel non-enseignant dans les établissements supérieurs en France. Paris: Observatoire national de la vie étudiante.

4. Dubet, F. (1994). Dimensions et figures de l'expérience étudiante dans l'université de masse. Revue française de sociologie, 35 (4), 511-532.

5. Fave-Bonnet, M. F. (2003). Conflits de missions et conflits de valeurs: la profession universitaire sous tension. Connexions, 78, 31-46.

6. Felouzis, G. (2001). La condition étudiante. Paris: PUF.

7. Ferone, G. (2011). Favoriser les interactions à distance en formation des maîtres. Recherche \& Formation, 68, 79-94.

8. Guyot, Y. (1979). Obstacles à la communication dans l'enseignement supérieur. Thèse de doctorat. Université Paris.

9. Hadji, C., Bargel, T., \& Masjuan, J. (2004). Étudiés dans une université qui change : le regard des étudiants de trois régions d'Europe. Grenoble: PUG.

10. Lahire, B. (2000). Conditions d'étude, manières d'étudier et pratiques culturelles. In C. Grignon (Ed.), Les conditions de vie des étudiants (pp. 241-381). Paris: PUF.

11. Martuccelli, D. (1995). Décalages. Paris: PUF.

12. Merle, P. (1997). Le rapport des étudiants à leurs études: enquête sur trois populations scolarisées dans des filières "fermées" et "ouvertes". L'Orientation scolaire et professionnelle, 26, 367-387.

13. Mykytiuk, H. Yu. (2003). Vzaiemyny vykladachiv zi studentamy yak chynnyk stanovlennia osobystosti maibutnoho vchytelia. (Dys. kand. psykholoh. nauk). Natsionalnyi pedahohichnyi universytet imeni M. P. Drahomanova, Kyiv.

14. Pinel, J.-P. (2003). Malaise dans la transmission: l'Université au défi des mutations culturelles contemporaines. Connexions, 78, 11-30.

15. Yurchenko, V. (1998). Otsinni stavlennia v pedahohichnii vzaiemodii. Osvita $i$ upravlinnia, 4, 91-98. 